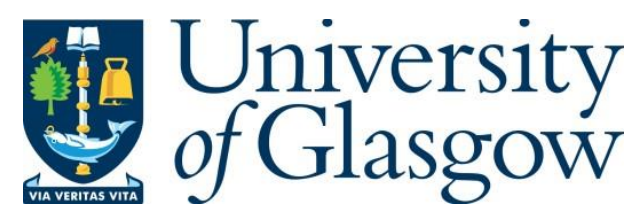

Felbo-Kolding, J., Leschke, J. and Spreckelsen, T. F. (2019) A division of labour? Labour market segmentation by region of origin: the case of intra-EU migrants in the UK, Germany and Denmark. Journal of Ethnic and Migration Studies, 45(15), pp. 28202843.

There may be differences between this version and the published version. You are advised to consult the publisher's version if you wish to cite from it.

http://eprints.gla.ac.uk/205429/

Deposited on: 29 January 2020

Enlighten - Research publications by members of the University of Glasgow http://eprints.gla.ac.uk 


\title{
Labour market segmentation by region of origin: The case of intra-EU migrants in the UK, Germany and Denmark ${ }^{1}$
}

\author{
Jonas Felbo-Kolding, ${ }^{a}$ Janine Leschke ${ }^{\mathrm{b}}$ and Thees Spreckelsen ${ }^{\mathrm{c}}$ \\ ${ }^{a}$ Department of Sociology, University of Copenhagen, Copenhagen, Denmark; ${ }^{b}$ Department of \\ Business and Politics, Copenhagen Business School, Copenhagen, Denmark; ${ }^{c}$ Department of Social \\ Policy and Intervention, University of Oxford, Oxford, UK.
}

\begin{abstract}
The EU enlargements of 2004 and 2007 made CEE citizen legally equal EU labour market participants. However, CEE immigrants still face 'racialisation' and segmentation in NorthWestern Europe in terms of labour market integration. Similar processes might extend to EUSouth migrants, giving rise to a division of labour, whereby CEE and EU-South migrants find poor-quality, low-pay jobs in the North-Western EU labour markets.

We compare the labour market integration of four groups of recent intra-EU migrants (EU8, EU2, EU-South and EU-West/EEA) in the UK, Germany and Denmark. Using labour force, microcensus and register data, we measure quantitative labour market integration through labour force participation, and qualitative integration through hourly wages.

Despite differences in migration trends, labour markets and welfare regimes, we find a consistent pattern of labour market segmentation along occupational and industry lines amongst recent EU immigrant groups in the three countries. EU-West/EEA immigrants out-perform both natives and all other immigrant groups in terms of wages. EU8 and EU2 immigrants have high employment propensities, but also lower wages. EU-South immigrants have lower wages and lower employment propensities. These findings require replication across the North-Western EU countries; however, they suggest that inequalities across the EU are being reproduced rather than converging.
\end{abstract}

1 The parts on Germany and the UK have received funding from the European Union's Seventh Framework Programme for research, technological development and demonstration under Grant Agreement no. 613256. The Danish part of this paper was supported by a grant from the Danish Ministry of Employment. 
Keywords: intra-EU migration; labour market integration; wages; segmentation; welfare regimes 


\section{Introduction}

EU citizens consider the right to freedom of movement within the European Union to be the most important individual benefit of EU membership (Recchi 2015). Indeed, the 2004 and 2007 EU enlargement rounds to Central and Eastern European (CEE) countries hugely increased intra-EU labour mobility (Kahanec \& Zimmermann 2016), with European citizens representing $40 \%$ of the total EU migrant population in 2014 (Castro-Martin \& Cortina 2015). The central premise of the right to free movement for workers as laid out in article 45 of the Lisbon Treaty is that EU citizens working in another member state are not discriminated against based on their nationality as regards employment, remuneration or other working conditions. However, equal legal rights do not guarantee equal labour market outcomes.

Previous research (mainly on the UK) has shown that CEE immigrants, in particular, have worse labour market outcomes than natives in the destination country in terms of skills-occupation match (Bettin 2012; Clarke \& Drinkwater 2008; Johnston et al. 2015) and that they are over-represented in industries characterised by low-pay and low-skill jobs (Barrett, McGuinness \& O’Brien 2012; Friberg et al. 2014; Khattab \& Fox 2016; Recchi 2015). Additionally, CEE immigrants in Western Europe have lower wages than immigrants from the former EU15 countries (Barrett, McGuinness \& O’Brien 2012; Clarke \& Drinkwater 2008; Voitchovsky 2014).

Such systematically poorer labour market outcomes pose a challenge to the premise of equality as well as to the legal demand for non-discrimination of EU migrant citizens. Moreover, they challenge a fundamental tenet of the ever-closer European Union project, where workers' mobility is seen as a key driver of economic growth for the EU - as outlined in key EU documents, including the New Skills Agenda for Europe and Youth on the Move.

Recent research focuses almost exclusively on the labour market situation of CEE immigrants in Western European countries. This reflects the steep increase in CEE immigrant inflows since accession, which has also been driven by the considerable economic differences between the EU8 ${ }^{2}$ and EU2 (Bulgaria and Romania) member states, on the one side, and the 'old' member states

2 Czech Republic, Estonia, Hungary, Latvia, Lithuania, Poland, Slovakia, Slovenia. 
(EU15), on the other. Most of this research focuses on the UK and compares CEE immigrants (more particularly immigrants from the EU8 and in most cases Poles) with nationals and sometimes with EU15 immigrants. Several scholars have suggested that a new 'racialisation' and a resulting segmentation of EU immigrants has developed since accession, with CEE immigrants faring worst in North-Western Europe (Diehl et al. 2015; Favell 2008; Favell \& Nebe 2009).

Poorer labour market outcomes amongst CEE immigrants are often attributed to discrimination (Fox et al. 2015; Demireva \& Kesler 2011) and differential power relations, as well as to exclusion by employers from some occupations (Clarke \& Drinkwater 2008; Johnston et al. 2015; Parutis 2011; Voitchovsky 2014). Another explanation could be differences in reservation wages (given the different levels of earnings across Europe, see Eurostat 2017) and in welfare state generosity, which affects the value of portable benefits across member states (Bruzelius et al. 2017). These differences will enable immigrants from more affluent countries (EU-West/EEA) - in contrast to immigrants from poorer countries - to look on average for a longer period of time for suitable jobs and to move only when they can be sure of getting a good match. CEE immigrants, by contrast, will be more inclined to take up jobs in the destination country that are low-wage and low-skilled and for which they are over-qualified (Khattab \& Fox 2016).

As a result, a new division of labour across the EU seems to be emerging, where CEE and potentially Southern European labour migrants are taking up jobs at the bottom of the labour market. They thereby end up achieving poorer qualitative labour market outcomes in EU15 destination countries than their peers from the EU-West and EEA ${ }^{3}$.

However, to establish whether such a division of labour across the EU actually exists, different groups of intra-EU immigrants need to be compared, and few studies do so (for notable exceptions, see Barrett, McGuinness \& O’Brien 2012; Clarke \& Drinkwater 2008; Johnston et al. 2015; Voitchovsky 2014). Crucially, previous studies rarely look at EU-South ${ }^{4}$ immigrants as a distinct

3 Nationals from the four EEA countries (Iceland, Liechtenstein, Norway and Switzerland) enjoy the same freedom of movement with regard to labour as EU citizens. They are among the most affluent countries in Europe (Eurostat 2017).

4 Greece, Italy, Portugal, Spain, Cyprus and Malta. 
group. Following the economic downturn in the aftermath of the 2008 economic and financial crisis, skyrocketing unemployment and the subsequent steep increase in migration flows from these countries, inclusion of EU-South migrants as a separate group seems pertinent. In Southern Europe, high unemployment rates and to some degree also reservation wages are likely to act as economic push factors. Spreckelsen et al. (forthcoming) show descriptively that recent (young) immigrants from the EU-South in the UK and Germany seem to fare worse in terms of wages and skills-occupation match than immigrants from EU-West/EEA countries.

Second, the labour market outcomes of the different groups of EU immigrants need to be compared across different national or institutional settings. Most studies examining the labour market situation of EU migrant citizens focus on the UK or on some other single country (see e.g. Barrett, McGuinness \& O'Brien 2012). This is problematic (particularly in the context of different institutional configurations and transition regimes following the enlargements) if, as we claim, a division of labour should be observable amongst EU migrant citizens in general. Using country-level micro data and regression analyses, this article therefore investigates whether both a quantitative and qualitative division of labour exists among recent intra-EU immigrants in three distinct labour market and welfare regimes - the UK, Germany and Denmark.

The overall hypothesis of our paper is that more than ten years after the establishment of a common EU labour market across the old East-West boundaries, we find a clear labour market segmentation in terms of qualitative labour market outcomes by region of origin while accounting for individual characteristics. And this despite legal equality and the end of transition measures for the majority of 'new' EU citizens. We expect the quantitative labour market outcomes of recent EU immigrants in terms of employment propensity to be similar to those of nationals, given that they have unrestricted labour market access and are on average young and relatively highly educated. Because of remaining hurdles, including language challenges and possible discrimination by employers, some differences are likely to remain. Given the general openness of the UK labour market, we expect intra-EU immigrants to fare comparatively better in the UK than in Germany and Denmark. Turning to qualitative outcomes and based on occupational and industry segmentation - i.e., a division of labour created by discrimination, driven by 'racialisation' and economic push factors (differences in reservation wages and unemployment rates) - we expect to see immigrants from the EU-West and EEA countries doing better in terms of wages than those from Southern Europe. We expect CEE immigrants to show the poorest outcomes. This segmentation, we propose, reflects a distinct division 
of labour by macro regions of origin across the EU, independent of the receiving countries' labour market and welfare regime types.

\section{Labour market segmentation of immigrants in Western Europe: Theoretical explanations and hypotheses}

On a macro level, segmentation theory (Piore 1979) provides two explanations for the expected division of labour in the EU. First, it argues that because of structural demand, all modern industrialised economies have a secondary labour market segment characterised by low skills and poor working conditions, which is unattractive to native workers but filled by often temporary labour migrants with lower reservation wages because of their different frame of reference (Piore 1979). Second, this labour demand mechanism of segmentation is counteracted by labour market institutions and welfare state arrangements (Peck 1996; Rubery 2007). Both theoretically and empirically, the different destination countries and their respective institutional configurations (e.g., labour market or welfare regimes) should therefore play a moderating role in the degree of segmentation we would expect (Esping-Andersen 1990; Hall \& Soskice 2001) from the general segmentation mechanisms. However, we know little about the role of institutional configurations in the segmentation of intra-EU migration because most existing studies have focused on a single country, often the UK.

Consequently, this article focuses on Denmark, Germany and the UK. Each country represents dominant labour market and welfare state configurations characterising the North-Western EU member states, with varying strengths of the role of state, market and family: Denmark represents the social-democratic welfare regime; Germany, the conservative regime and - in Varieties of Capitalism (VOC) terminology - a coordinated market economy; and the UK, the liberal regime and in VOC terms a liberal market economy. It is important to note that these typologies are highly relevant for labour market segmentation and dualisation (e.g., Häusermann and Schwander 2012), Thus, we expect the UK to have more equal outcomes in terms of employment between nationals and EU migrants than Germany and Denmark because of the predominance of general as opposed to specific skills in the (thus more open) UK labour market. However, in the context of intra-EU migration, we posit that the institutional configurations only moderate the more prominent countryof-origin differences discussed below. 
On a micro level, employer discrimination by nationality or ethnicity (Kingston et al. 2015; Ebner \& Helbling 2016; Fossati et al. 2017), language barriers and insufficient recognition of skills (Chiswick \& Miller 2007), as well as differences in reservation wages (Amuedo-Dorantes \& De La Rica 2007) are known to influence job choices and prospects (European Commission 2017).

The theoretical explanations above correspond to the observations of macro-level migrant-native segmentation patterns. Previous research has found nationals to be better integrated than migrants in their respective labour markets (Nielsen et al. 2004); similarly, Western migrants consistently do better than their non-Western counterparts (Brodman \& Polavieja 2010). Likewise, immigrants consistently find it easier to gain access to the UK than to the German and Danish labour markets (Algan et al. 2010), albeit often through atypical jobs (Ballarino \& Panichella 2015; McCollum \& Findlay 2015).

The segmentation mechanisms identified above affect immigrants in general. However, EU and EEA immigrants are a legally and economically distinct group, different both to nationals and to thirdcountry immigrants. The overall migrant versus nationals segmentation effects should be less pronounced for EU/EEA than for third-country immigrants. This is because of EU initiatives on transparency and recognition of skills and qualifications, as well as a weaker dependence on the new destination labour market for EU immigrants than for third-country workers. Although CEE immigrants were recently restricted to some degree by transition measures - indeed up to 2011 for EU8 citizens in Germany and up to 2013 for EU2 immigrants in Germany and the $\mathrm{UK}^{5}$ - freedom of movement implies that EU immigrants can easily move for work from one member state to another and easily return to their country of origin. This mobility is also facilitated by shorter distances and lower transport costs (Black et al. 2010).

At the same time, particularly with the accession of the CEE member states, but also as an outcome of the recent economic and financial crisis (which particularly affected the economies of Southern Europe), the EU countries are very heterogeneous in terms of economic and welfare state developments. Compared to EU-West/EEA member states, CEE countries have considerably lower nominal wages - the post-accession catch-up having been partly reversed by the 2008 crisis

5 Transition measures for EU2 citizens were abolished in Denmark as of 1 May 2009. 
(Galgóczi 2017) - and also have less developed welfare states. To a lesser extent, this is also the case for Southern European member states; after a convergence period, the 2008 economic crisis and the subsequent surge in unemployment and the austerity pressures on wages and welfare systems all widened the gap to Northern Europe (Lehndorff 2015). A decisive factor here are the high youth unemployment rates since the economic crisis, which constitute an important push factor for migrants. The relatively good economic conditions in their home countries, by contrast, means EUWest/EEA immigrants are less likely to have migrated because of economic push factors, whereas economic pull factors should still be at play. Consequently, the mechanisms outlined in segmentation theory should - because of differences in the selectivity of emigration - (Chiswick 2008) vary according to the country/region of origin of EU migrants, potentially leading to a division of labour among EU migrants.

Two factors, in particular, could create segmentation between groups of $(E U)$ immigrants and, in particular, between CEE immigrants and EU-West/EEA immigrants, with EU-South immigrants potentially taking a middle position: differences in employer discrimination deriving from racialisation; and economic push factors, in particular reservation wage differentials and high unemployment. Additionally, transition measures are likely to have played a role in restricting to some degree the free choice of employment.

First, a process of racialisation leads to CEE and EU-South immigrants being perceived as distinct from EU-West/EEA immigrants in terms of language and culture (Favell 2008; Favell \& Nebe 2009; Fox et al. 2015), leading to experiences of discrimination. This mechanism has empirically been shown to lead to poorer labour market outcomes at least for CEE immigrants in terms of occupational segmentation and hence wages (Fox et al. 2015; Demireva \& Kesler 2011). In particular, such discrimination seems to relate to the hiring of CEE immigrants for specific jobs: employers' perception of CEE immigrants' work ethic and flexibility has meant that employers prefer them to native workers, especially for low-skill, routine, manual jobs (Hopkins \& Dawson 2016; McCollum \& Findlay 2015). Paradoxically, employers' general perceptions of CEE immigrants may thus translate into high overall employment levels, while at the same time hindering their transition out of the secondary labour market. The racialisation and ensuing discrimination on the part of employers might therefore lead to a systematic sorting of different immigrant groups into different jobs based on their region of origin (Constant \& Massey 2005). 
Second, lower reservation wages among CEE immigrants because of sizeable region-of-origin versus country-of-destination wage differentials, are likely to make CEE immigrants more willing to accept low-pay, low-skill jobs. Short-term labour migration will be especially affected, where an immigrant accumulates wages in the destination country but regularly returns to and consumes in the country of origin or otherwise transfers earnings (Drinkwater \& Garapich 2015). The expected wage differences have been consistently observed for CEE immigrants (with a focus on the UK: Dustmann et al. 2010; Johnston et al. 2015; Pietka et al. 2013; Trevana 2013). Consequently, the intra-EU differentials in wages and potentially also portable unemployment benefits (Bruzelius et al. 2017) seem to increase the likelihood of EU immigrants from poorer member states taking on lower paid and lower skilled jobs (Khattab \& Fox 2016). In line with very high unemployment rates and more limited welfare state cushioning as push factors, Spreckelsen et al. (forthcoming) and Akgüc and Beblavý (forthcoming) find poorer qualitative labour market outcomes for young immigrants from the EUSouth as compared to the EU-West in North-Western destination countries. EU-West/EEA immigrants, on the other hand, have better employment opportunities and qualitative outcomes at home and are thus less likely to migrate to take up low-skill, low-pay employment (Chiswick \& Miller 2011).

Building on the above theoretical arguments and previous empirical findings, we expect that:

Hypothesis 1 on quantitative integration: Recent EU migrants, given their legally unrestricted labour market access and their profile (young and highly educated), have relatively high labour force participation (employment propensity), particularly as compared to third-country migrants.

Hypothesis 2 on qualitative integration: Recent intra-EU migrants from EU-West/EEA earn higher wages than recent EU migrants from EU8 and EU2 countries, with EU-South migrants taking a middle ground.

Further, we expect this division of labour to manifest itself in:

Hypothesis 3: Consistent labour market segmentation in terms of qualitative outcomes across all three types of institutional configurations represented by Denmark, Germany and the UK, despite their different welfare state and labour market institutions. 
Hypothesis 3a: Because English is a lingua franca and the UK labour market is more permeable given its need for general rather than specific skills, immigrants in the UK are expected to have labour market outcomes that are closer to those of natives than immigrants in Germany or Denmark.

\section{[Figure 1 near here]}

\section{Data and methods}

Region of origin is defined using the following six categories; natives (British, German or Danish ${ }^{6}$ ); EU-West/EEA consists of EU15 (excluding EU-South) and EEA citizens; EU-South; EU8; EU2; and third-country nationals (TCNs). ${ }^{7}$ We look at recent immigrants ${ }^{8}$ who arrived within the last five years; this is a considerable share of EU28 migrants (European Commission 2017). Region-of-origin effects are best studied in recent migrants (Rienzo 2013) because over time migrants tend to catch up or assimilate with their native peers.

6 In the analyses of the UK, Germans and Danes are included in the EU-West/EEA group and vice versa.

7 Third-country nationals (TCNs) are immigrants coming from countries outside the EU/EEA. We acknowledge that this is a very broad group, but as our research focus lies on intra-EU migrants, we do not attempt to divide it up further.

8 For the UK, immigrants are identified as having a different country of birth than the UK, no UK citizenship, and UK residency for between one and five years. For Germany, immigrants are identified as having nonGerman citizenship and having migrated to Germany within the previous five years. For Denmark, immigrants are identified as having a different country of birth and having officially settled in Denmark between one and five years ago. 
Our analyses are based on data from the German Microcensus ${ }^{9}$ (2013) and pooled data (2012-2014) from the UK quarterly Labour Force Survey (UK-LFS), ${ }^{10}$ both of which have relatively comparable sampling designs and indicators as inputs to the European Labour Force Survey (EU-LFS). For Denmark, we use administrative register data ${ }^{11}$ (2014). The UK-LFS is likely to underestimate migrant populations (Longhi and Rokicka 2012; Martí and Ródenas 2007) and we expect similar effects for the German Microcensus given its German-only questionnaire (the interviewers are given translation assistance into English). The one limitation of the Danish administrative data is that it only covers the resident population. All three data sets inadequately cover short-term migrants (e.g., seasonal workers, posted workers) and cross-border commuters.

\section{Dependent variables}

We investigate overall quantitative labour market integration by measuring labour market participation defined as active (employed or unemployed) versus inactive (ILO) labour market

9 The Microcensus is a representative sample containing demographic and labour market information from 1\% of all households in Germany. All persons who have right of residence in Germany, whether living in private or collective households, or at their main or secondary residence, are sampled and are obliged to participate (Research Data Centre of the Federal Statistical Office and Statistical Offices of the Länder 2016).

10 The LFS is the largest social survey in the UK. All adult members from a rotating sample of 41,000 private households are interviewed in five consecutive quarters. The sample size makes it the best data set available for analysing the labour market situation of recent immigrants (Office for National Statistics (ONS) 2015a).

11 Danish administrative register data cover the total population of residents in Denmark, both immigrants and natives. The analysis of employment, unemployment and inactivity uses a register indicating the primary labour market status (ILO definitions) of every resident at the end of each November. For the analysis of wages and working hours, a register containing information on everyone active in the labour market during the year is used to calculate average hourly wages throughout the year. 
status. $^{12}$ This approach captures employment propensities and thus allows us to assess labour market openness and selection processes according to region of origin.

We examine qualitative labour market integration by means of hourly wages. These are measured in the Danish data by dividing the total average earned income as recorded by the tax office and reported by employers by the number of actual hours worked. In the German data, net hourly wages are derived from net wages in the month prior to the survey, available only in earnings classes. ${ }^{13}$ The UK-LFS provides net hourly pay directly. ${ }^{14}$

\section{Explanatory variables}

To assess segmentation, we use a 'region of origin' variable that consists of six groups: natives, EUWest/EEA, EU-South, EU8, EU2 and TCNs.

\section{Control variables}

All models include demographic and household characteristics: age, age squared, gender; two household characteristics: presence of a dependent child $(<16)$ in household and the employment status of the partner (no partner in household, partner not employed, partner part-time employed, partner full-time employed) (cf. Warren 2004; O’Reilly \& Fagan 1998).

12 According to the EU-LFS definition, persons working at least one hour in the reference week and persons who were not active in the reference period, but had a job from which they were temporarily absent, are counted as employed and asked questions relating to their employment status. Economically inactive persons are those who are neither employed nor unemployed.

13 The mean of the respective wage class is divided by the normal working hours. We limit the German analysis to persons whose main source of income are wages from work because the information in the Microcensus not only contains wages from work but also, for example, child benefits and income from renting out property(for details, see Engels et al. 2012, pp. 198ff).

14 Wages have been adjusted for inflation using the Consumer Price Index (ONS 2015) on the pooled data. 
We include occupation (one-digit ISCO08) and, alternatively, employment sector (one-digit NACE) to account for the existence of immigrant occupation niches and their clustering in specific industries such as construction and hospitality. ${ }^{15}$

Information on qualification/education is not available in administrative registers for Denmark but is included in additional models for the UK and Germany, which are presented in the appendix. For Germany, we use the International Standard Classification of Education (ISCED) (Schroedter et al. 2006). ${ }^{16}$ For immigrants in the UK, only an origin-of-qualification variable is available (none, from school, work-related, from university).

\section{Statistical analyses}

We model labour market participation using multivariate logistic regressions and model wages through a linear regression of log hourly wages (cf. Chiswick et al. 2005) in Stata 14.0 (StatCorp, College Station, TX). The UK analyses account for sampling design; the German models use standard weights, which account for non-response adjusting for demographic factors, namely age and nationality in broad groups, both separately for men and women. To assess the relative contribution of our variables, we start with a baseline model of region-of-origin differences, subsequently adding demographic, employment and migration characteristics. All analyses are restricted to the workingage population (aged 16-66, excluding students and retirees).

\section{Results: Segmentation by region of origin?}

\section{Demographic characteristics of EU immigrants in the UK, Germany and Denmark}

Table 1 shows that recent EU immigrants are on average at least eight years younger than the native population. Men historically have tended to dominate flows of labour immigrants (Castles et al. 2013). However, among recent EU immigrants there is no clear pattern of gender distribution across

15 The German and UK data do not have sufficient case numbers to include both variables in one model.

16 These are created using standard routines available here: http://www.gesis.org/en/missy/metadata/MZ/ 
the regional groups within the three countries studied. The average time since arrival does not differ substantially across the three countries or migrant groups: EU-South immigrants have arrived somewhat more recently, which is in line with the trends developing since the economic crisis. Given the small variation in years since arrival between regions of origin and given that catching up takes more than five years (Chiswick 1978), we do not control for 'length of stay' in the regression models.

\section{[Table 1 near hear]}

\section{Regression results}

\section{Quantitative labour market integration: Labour force participation}

Table 2 reports the results of two logit regression models where labour force participation (employed or unemployed vs. inactive) is the dependent variable. While information on the labour market attachment (employed vs. unemployed) of migrants vs. nationals is interesting in its own right because it provides a more complete picture of their labour market integration, it is not relevant for our theoretical argument. For completeness, we display the results in appendix 1 (table 1).

Model 1 shows the baseline regions-of-origin model, while model 2 controls for demographic and partners' employment characteristics. The only results that are consistent across all three countries are that recent TCNs are significantly less likely than nationals and all other recent migrant groups to participate in the labour market. This is in line with previous research, which has found non-Western migrants to do worse than EU migrants, and supports hypothesis 1 (Brodmann \& Polavieja 2010).

In Denmark and Germany, all recent EU immigrant groups are doing worse in terms of labour market participation than nationals. In the UK, by contrast, controlling for demographics, differences in labour market participation are not significant for any of the EU immigrant groups. When we look at the baseline model, we see that labour market participation is significantly higher for EU8 and EU2 citizens than for nationals.

In Denmark, controlling for demographics, the difference between the labour market participation of EU immigrants compared to nationals is statistically significant and is smaller for EU2 and EU8 immigrants (model 2). The coefficients for recent EU-West/EEA and EU-South immigrants are 
similar in magnitude and both groups display greater differences vis-à-vis nationals than EU2 and EU8 immigrants in terms of likelihood of participation in the labour force. For EU immigrants in Germany, controlling for demographic characteristics, the ordering of the immigrant groups is somewhat different, with EU-West/EEA and EU8 immigrants being more similar to nationals as regards labour force participation than EU-South and EU2 nationals (model 2).

One explanation for the difference in quantitative labour market integration across groups and the two destination countries might be the impact of established migrant social networks (Waldinger \& Lichter 2003) and of transitional arrangements (Fihel et al. 2015) on finding employment in the first place. We cannot control for these possibilities, but a Danish study on long-term CEE immigrants found that more than half had secured a job in Denmark prior to migrating (Felbo-Kolding 2016).

For all three countries, controlling for demographic characteristics attenuates the differences relative to the respective nationals - a result driven by higher employment propensities for young people, with immigrants being proportionally younger. While the German and Danish results remain significant and negative, for the UK only TCNs exhibit an even stronger negative and statistically significant difference to UK nationals, while the effects on the other groups become insignificant.

Overall, the results support hypothesis 1 that EU immigrant groups, thanks to freedom of movement, have relatively high employment rates relative to nationals and TCNs, but still do worse than nationals, except in the UK. The results for the UK are in line with the liberal labour market regime characterised by general skills as identified in VOC (Hall \& Soskice 2001) and also with more recent empirical research stressing the general openness of the UK labour market (Algan et al. 2010). These results support hypothesis $3 \mathrm{a}$.

However, the results also highlight a potential selection process whereby a larger proportion of Denmark's and the UK's CEE immigrants participate in the labour market compared to other EU immigrants. In Germany, a similar selection process takes place, but here EU-West/EEA and EU8 immigrants are more likely to gain access. Previous studies have shown that this selection process entails a positive selection either by the immigrants themselves because, for instance, of differences in reservation wages (Khattab \& Fox 2016) or by the employers on the basis of discrimination (Demireva \& Kesler 2011; Fox et al. 2015), so that those immigrants who do gain access are positively selected from the most able immigrants within the overall immigrant group from the different regions of origin (Chiswick 2008; Constant \& Massey 2005). The logic is that in groups where fewer immigrants gain access, those who do are likely to be more able than the average among 
selected immigrants in groups where more immigrants gain access; this selection, in turn, might lead to differences in qualitative labour market outcomes.

\section{[Table 2 near here]}

\section{Qualitative labour market integration: Hourly wages}

Log hourly wages are analysed in three steps (for results, see table 3). We first run a baseline model (1). In a further step (not shown), we add demographic information (age, gender, household composition and employment status of partner). This is particularly relevant given the strong variation in average age between nationals and immigrants (table 1) and thus the fact that some of the potential disadvantages experienced in terms of wages are simply due to age differences. Given that the previous literature on CEE immigrants' labour market integration has found that their poor performance in terms of wages compared to natives is due to labour market segmentation (e.g., Johnston et al. 2015), in models 2 and 3 we additionally add control variables related to the type of job the individual holds. Model 2 controls for the effect of the concentration of immigrants in certain industries, while model 3 controls for broad occupation groups. For Germany and the UK, we repeat model 3 with additional information on education/qualification, which leaves the results pretty much unchanged (see table 2, appendix).

Our models show substantial differences in log hourly wages between immigrant groups according to their region of origin. The most consistent finding across all three destination countries is that not only do migrants from EU-West/EEA perform better than migrants originating from CEE countries and EU-South (as well as TCN migrants), as predicted in hypothesis 2, but they also out-perform nationals in terms of wages. The remaining results are less consistent across the three countries and model specifications, although the coefficients are generally negative and significant in model 1 and either in model 2 with sectors or in model 3 with occupations. This indicates that immigrants from less affluent countries with poorer overall economic conditions earn lower log hourly wages than nationals (and EU-West/EEA migrants) across three different welfare state and labour market configurations (represented here by Denmark, Germany and the UK), supporting hypothesis 3.

We cannot, however, confirm a clear ranking of EU-South, EU8 and EU2 migrants - as predicted in hypothesis 2 - across all model specifications and all three destination labour markets. Controlling 
for demographics and industry (model 2), a consistent ordering of migrants from less affluent countries emerges - in line with our expectations - for Germany and Denmark. For the UK, in turn, the ordering is EU-South, EU2 and EU8. Model 2 also shows that in the case of EU-South immigrants, industry segmentation accounts for much of the difference vis-à-vis nationals, rendering the differences indistinguishable in Denmark and the UK. While controlling for industry segmentation changes the picture considerably for EU-South immigrants, for the other groups it generates more limited reductions in the effect size as compared to the base model than model 3 with occupations. The results of model 3 clearly show that for EU8 and EU2 immigrants, the largest part of their disadvantage vis-à-vis natives can be explained by their concentration not in specific industries - as various studies have previously suggested (Arnholtz \& Hansen 2013; Bettin 2012; Drinkwater \& Garapich 2015; Friberg et al. 2014) - but in specific low-pay occupations across different industries. Controlling for occupation in fact renders the difference between UK nationals and EU8 and EU2 immigrants insignificant. This supports hypothesis 3a, which predicted that immigrants in the UK will be more similar to natives. The effects become very small for EU8 and EU2 immigrants in Denmark. In Germany, due to effect-size reduction for EU8 nationals as compared to the model with industry controls, controlling for occupation makes the differences between EU-South and EU8 indistinguishable, although they still have poorer outcomes than nationals. Also, across all three destination countries, the advantage in terms of log hourly wages is substantially reduced for EU-West/EEA immigrants when we control for occupations rather than for sectors.

The fact that effects for EU-South migrants, in contrast to all other EU migrant groups, are larger when we control for industries rather than for occupations calls for further research that also investigates potential interactions between occupations and sectors. This was not possible here because of limited case numbers for Germany and the UK, in particular.

\section{[Table 3 near here]}

\section{Discussion and conclusions}

This paper provides evidence of a division of labour between different groups of recent intra-EU immigrants in three destination countries with different labour market and welfare state regimes. It uses country-level micro data from the UK, Germany and Denmark, distinguishing between different groups of intra-EU immigrants and third country nationals. In line with previous research - often 
with a single-country focus (usually the UK) - we distinguish between EU-West/EEA, EU8, EU2 and EU-South regions of origin. This categorisation provides new insights concerning the EU-South as a distinct group, underpinned by the considerable labour market disruption that has followed the economic crisis. We also compare and contrast EU8 and EU2, recognising their later EU entry but also their distinctly different economic and political trajectories during the post-socialist transformation.

We separately analyse and contrast models on quantitative and qualitative labour market integration so as to capture differential selection into and within labour markets. These models corroborate the expected advantage of EU immigrants vis-à-vis third-country migrants, given the formers' relatively unrestricted access to other EU member states' labour markets. This holds across all three destinations, despite their very different migration histories with regard to third-country migrants (e.g., Commonwealth and post-colonial migration in the UK, guestworker programmes in Germany and Denmark, and in Germany also ethnic German immigrants) and different recent transition regimes. Similarly, and as expected, the results for EU immigrants' labour force participation vis-àvis nationals support our hypothesis that the UK has a more permeable labour market than Germany or Denmark. This could be explained by the importance of general rather than specific skills as proposed in the VOC literature and by the status of English as a lingua franca.

We were particularly interested in qualitative labour market integration, which - notwithstanding other relevant measures of integration such as contract type or skills-occupation match - we captured using log hourly wages. Notably, we found segmentation by region of origin across all three destination countries. While EU-West/EEA immigrants consistently did better than both nationals and all other immigrants, the ranking among the other EU immigrant groups was more complex. Although the picture resulting from the models is complex, it is safe to say that recent EU-South immigrants have more in common with CEE immigrants than they do with EU-West/EEA immigrants when it comes to qualitative labour market outcomes. This finding is in line with the propositions of segmentation theory, reflecting reservation wage differences and push factors such as high unemployment rates, and might be related to racialisation by region of origin. Crucially, the segmentation could be observed despite variations in labour market and welfare state arrangements, as repeatedly postulated since Esping-Andersen's seminal work (Arts \& Gelissen 2002), and to a degree irrespective of the demographic characteristics of the EU migrants. This suggests that country/region-of-origin differences are at least as important as country-of-destination differences. 


\section{Potential explanations and mechanisms}

The fact that occupational and to a lesser degree industry segmentation account for most of the variation in qualitative labour market outcomes across the three different labour market and welfare configurations indicates that more than ten years after the EU enlargement of 2004, a clear division of labour has developed. In this division of labour, EU-West/EEA immigrants are able to move more or less 'invisibly' (Favell \& Nebe 2009) between jobs that on average are even better than those occupied by nationals within the region of the North-Western EU, regardless, for example, of cultural and language differences. EU-South immigrants who have - at least in recent decades enjoyed the same 'invisible' mobility in the aftermath of the crisis seem to take up a position closer to that of CEE immigrants than to that of nationals or EU-West/EEA immigrants, in line with what Favell \& Nebe (2009) suggest. They even struggle to gain access to the destination labour markets at the same rates as CEE immigrants and, once they do gain access, they are (similar to the CEE immigrants) sorted into jobs at the bottom of the ladder. EU8 immigrants seem to occupy a position very similar to that of EU-South immigrants, though with higher employment rates. This pattern suggests that EU8 immigrants have established themselves in the destination labour markets and that employers see this group as a reliable and flexible source of labour, especially for low-pay, lowskilled jobs (Hopkins \& Dawson 2016; McCollum \& Findlay 2015). At the same time, EU8 migrants have managed to establish social networks that facilitate entry into the labour market, albeit with uncertain qualitative outcomes (Waldinger \& Lichter 2003). The different density of social networks and different transitional arrangements might also account for EU2 immigrants' poorer performance in the intra-EU division of labour.

We are unable to disentangle the exact mechanisms behind the division of labour, but based on previous research, a combination of three mechanisms is likely at play. First, a positive selection process where only EU-West/EEA immigrants who are able to compete on the destination labour market or even improve their position vis-à-vis their country of origin migrate in the first place, because the relatively positive economic conditions in their home countries are unlikely to push them to leave. For EU-South migrants, in particular, and to a lesser extent for CEE migrants, the overall economic conditions in their home countries are likely to push more people to migrate. Second, the differences in home-country environments, particularly wage levels and cushioning welfare benefits, likely affect the migration groups' reservation wages differently. EU-West/EEA immigrants are likely to only take up employment above a relatively high wage level. By contrast, EU-South and, in particular, CEE immigrants may accept any employment available (Bruzelius et al. 2017). Third, 
differences in racial visibility to employers (Favell \& Nebe 2009) and the resulting differences in employer discrimination and recognition of skills lead to variations in the jobs that the different immigrant groups are found to be eligible for and can thus take up.

\section{Directions for future research}

These results should be considered both from a micro- and a macro-level perspective. On the macro level, the results underline the fact that legal or formal equality is no guarantee of equal labour market outcomes. In the case of EU labour migration, the division of labour seems less determined by overall legal provisions and more by persistent differences in wage levels and employment possibilities across the EU. Future research should therefore consider the country-level and EU-wide mechanisms through which the purported country/regional differences are replicated in the destination countries for EU immigrants. On a micro level, and crucial for policies on intra-EU mobility, future research needs to focus on the individual or group-level mechanisms that lead to widespread occupation and industry segmentation. The portability and levels of unemployment benefits and income support, language differences and the role of labour market intermediaries, and the nature of social networks all need to be considered as determinants of labour market segmentation. For example, what role do employer stereotypes and discrimination play? In what way do the different types and regulatory regimes for labour market intermediaries help replicate existing differentials across the EU as opposed to providing a means of equalisation?

Similarly, future research would need to examine the process of labour market integration among different groups of EU immigrants. In our article we have found a clear division of labour among recent intra-EU immigrants, but what would the picture look like if we had focused on longer-term immigrants? Consequently, we would need to study changes in integration over time. This need is compounded by recent studies finding that CEE immigrants increasingly settle long term in their destination countries (Felbo-Kolding 2016; Janicka \& Kaczmarczyk 2016). Length of stay improves migrants' specific human capital in the receiving country (Chiswick 1978), their social (recruitment) networks (e.g., Andersen \& Felbo-Kolding 2013 on the role of social networks in employers' recruitment of CEE immigrants in Denmark) and their language skills (Chiswick \& Miller 2007). However, this finding challenges the overall notion of short-term intra-EU mobility, where immigrants move according to the overall mechanisms of supply and demand, whilst at the same time it provides an opportunity to test the persistence of the division of labour found in this study. Finally, the position of EU-South immigrants found in this article marks an interesting topic for 
future research to see if their current position is transitory or if, even as economic conditions in their home countries improve, they remain in the lower echelons of the destination labour markets. 


\section{References}

Akgüç, M. \& Beblavý, M. (forthcoming). What happens to young people who move country to find work?, in: J. O’Reilly, J. Leschke, R. Ortlieb, M. Seeleib-Kaiser \& P. Villa. (eds.) 2018, forthcoming Youth Labor in Transitions, Oxford University Press.

Algan, Y., C. Dustmann, A. Glitz \& A. Manning. 2010. "The Economic Situation of First and Second Generation Immigrants in France, Germany and the United Kingdom”. Economic Journal, 120(542), 4-30

Andersen, S. K. \& J. Felbo-Kolding. 2013. Danske virksomheders brug af фsteuropaisk arbejdskraft. København: Museum Tusculanum Forlag

Amuedo-Dorantes, C \& S. De La Rica. 2007. "Labour Market Assimilation of Recent Immigrants in Spain”. British Journal of Industrial Relations 45(2), 257-284.

Arnholtz, J. \& N. W. Hansen. 2013. "Labour market specific institutions and the working conditions of labour migrants: The case of Polish migrant labour in the Danish labour market". Economic and Industrial Democracy 34, 401-422

Arts, W. \& J. Gelissen. 2002. “Three worlds of welfare capitalism or more? A state-of-the-art report”. Journal of European Social Policy 12(2): 137-158.

Ballarino, G. \& N. Panichella. 2015. "The Occupational Integration of Male Migrants in Western European Countries: Assimilation or Persistent Disadvantage?” International Migration, 53(2): 338352.

Barrett, A., S. McGuinness \& M. O’Brien. 2012. “The Immigrant Earnings Disadvantage across the Earnings and Skills Distributions: The Case of Immigrants from the New Member States" British Journal of Industrial Relations 50(3): 457-481.

Bettin, G. 2012. "Migration from the Accession Countries to the United Kingdom and Italy". In $E U$ Labour Migration in Troubled Times. Skills Mismatch, Return and Policy Response. B. Galgóczi, J. Leschke \& A. Watt. Farnham. Burlington: Ashgate 
Black, R., G. Engbersen, M. Okólski \& C. Panţîru, (eds.) 2010. A continent moving west? EU enlargement and labour migration from Central and Eastern Europe. IMISCOE Research Series. Amsterdam: Amsterdam University Press

Brodmann, S. \& J.G. Polaviejo. 2010. "Immigrants in Denmark: Access to Employment, Class Attainment and Earnings in a High-skilled Economy”. International Migration 49:1, 58-90

Bruzelius, C., C. Reinprecht \& M. Seeleib-Kaiser. 2017. “Stratified Social Rights Limiting EU Citizenship. Journal of Common Market Studies, Early View:

onlinelibrary.wiley.com/journal/10.1111/(ISSN)1468-5965/earlyview

Castles, S., H. de Hein, \& M. J. Miller. 2013. The Age of Migration. International Population Movements in the Modern World. 5th Edition. Basingstoke, United Kingdom: Palgrave Macmillan

Castro-Martin, T. \& C. Cortina. 2015.” Demographic issues of intra-EU European migration: Destinations, family and settlement”. European Journal of Population 31 (2), 109-125.

Clarke, K. \& S. Drinkwater. 2008. “The labour-market performance of recent migrants”. Oxford Review of Economic Policy 24 (3), 495-516.

Chiswick, B. R. 1978. "The Effect of Americanization on the Earnings of Foreign-Born Men.” Journal of Political Economy 86:5, 81-87.

Chiswick, B. R. 2008. “Are Immigrants favorably self-selected?” In Migration Theory. Talking across Disciplines $2^{\text {nd }}$ ed by C. B. Brettell \& J. F. Hollifield (eds.). New York, London: Routledge Chiswick, B. R. \& P. W. Miller. 2007. “Modeling Immigrants' Language Skills.” In Barry R. Chiswick (ed.) Immigration (Research in Labor Economics, Volume 27) Emerald Group Publishing Limited, $75-128$

Chiswick, B. R. \& P. W. Miller. 2009. “The International Transferability of Immigrants’ Human Capital." Economics of Education Review 28(2): 162-169

Chiswick, B. R. \& P. W. Miller. 2011. "The "negative" assimilation of immigrants: A special case". ILR Review 64(3): 502-525 
Chiswick, B.R., Y. L. Lee \& P. W. Miller. 2005. "Immigrant Earnings: a Longitudinal Analysis.” Review of Income and Wealth 51(4): 485-503.

Constant, A. \& D. S. Massey 2005. "Labor Market Segmentation and the Earnings of German Guestworkers." Population Research and Policy Review, 24(5): 489-512

Demireva, N., \& C. Kesler. 2011. "The Curse of Inopportune Transitions: The Labour Market Behaviour of Immigrants and Natives in the UK". International Journal of Comparative Sociology 52 (4): $306-326$

Diehl, C., M. Lubbers, P. Mühlau \& L. Platt. 2016. "Starting out: New migrants' socio-cultural integration trajectories in Four European Destinations“. Ethnicities 16(2): 157-179

Drinkwater, S. \& M. Garapich. 2015. "Migration Strategies of Recent Polish Migrants to England and Wales: Do They Have Any At All?" Journal of Ethnic and Migration Studies 41 (12), 19091931

Dustmann, C., T. Frattini \& C. Halls. 2010. “Assessing the Fiscal Costs and Benefits of A8 Migration to the UK." Fiscal Studies 31(1): 1-41

Ebner, C. \& M. Helbling. 2016. "Social Distance and labour Market Status of Immigrants in Switzerland." Work, Employment and Society 30:3, 436-454

Engels, D., R. Köhler, R. Koopmanns, \& J. Höhne. 2012. Zweiter Integrationsindikatorenbericht. Erstellt für die Beauftragte der Bundesregierung für Migration, Flüchtlinge und Integration. Köln/Berlin.

Esping-Andersen, G. 1990. The Three Worlds of Welfare Capitalism. Princeton, New Jersey: Princeton University Press

European Commission. 2017. 2016 Annual Report on intra-EU Labour Mobility. Brussels. Eurostat. 2017. "Statistics Explained: Wages and Labour Costs”. Accessed October 2017. http://ec.europa.eu/eurostat/statistics-explained/index.php/Wages_and_labour_costs 
Favell, A. \& T. M. Nebe. 2009. "Internal and external movers: East-West migration and the impact of the EU enlargement." In Pioneers of European Integration: Citizenship and Mobility in the EU. E. Recchi \& A. Favell (eds) Cheltenham: Edward Elgar, 205-23.

Favell, A. 2008. "The New Face of East-West Migration in Europe.” Journal of Ethnic and Migration Studies, 34 (5), 701-716

Felbo-Kolding, J. 2016. De blivende arbejdsmigranter i Danmark fra Polen og Rumanien. København: FAOS, Sociologisk Institut, Københavns Universitet, Forskningsnotat nr.149

Fihel, A., A. Janicka, P. Kaczmarczyk \& J. Nestorowicz. 2015. Free movement of workers and transitional arrangements: lessons from the 2004 and 2007 enlargements. Warsaw: Centre for Migration Research University of Warsaw.

Fossati, F., F. Liecthti, D. Auer \& G. Bonoli. 2017. 'Discrimination Multipliers - How Immigrants' integration affects labour market disadvantage.” MIM Working Paper Series 17:2, Malmø: Malmø University

Fox, J. E., L. Moroşanu \& E. Szilassy. 2015. “Denying Discrimination: Status, 'Race', and the Whitening of Britain's New Europeans.” Journal of Ethnic and Migration Studies 41(5): 729-748

Friberg, J.H., J. Arnholtz, L. Eldring \& F. Thorarins. 2014. "Nordic Labour Market Institutions and New Migrant Workers: Polish Migrants in Oslo, Copenhagen and Reykjavik". European Journal of Industrial Relations 20(1): 37-53

Galgóczi, B. 2017. "Why central and eastern Europe needs a pay rise.” ETUI Working Paper 2017.01, Brussels: ETUI, p. 10.

GESIS - Leibniz-Institut für Sozialwissenschaften (2017) Stata-Syntax zur Umsetzung der Bildungsklassifikation ISCED-1997 mit dem Mikrozensus 2012, German Microdata Lab (GML): https://www.gesis.org/en/missy/materials/MZ/tools/isced

Hall, P. A. \& D. Soskice. 2001. Varieties of Capitalism. The Institutional Foundation of Comparative Advantage. Oxford: Oxford University Press

Häusermann, S. \& H. Schwander. 2012. "Varieties of Dualization? Labor Market Segmentation and Insider-Outsider Divides Across Regimes." In: The Age of Dualization: The Changing Face of 
Inequality in Deindustrializing Societies edited by P. Emmeneger, S. Häusermann, B. Palier \& M. Seeleib-Kaiser. Oxford: Oxford University Press.

Hopkins, B. \& C. Dawson. 2016. "Migrant workers and involuntary non-permanent jobs: Agencies as new IR actors.” Industrial Relations Journal 47(2): 163-180

Janicka, A. \& P. Kaczmarczyk. 2016. "Mobilities in the crisis and post-crisis times: migration strategies of Poles on the EU labour market.” Journal of Ethnic and Migration Studies, 42 (10), 1693-1710.

Johnston, R., N. Khattab \& D. Manley. 2015. "East versus West? Over-qualification and Earnings among the UK's European Migrants.” Journal of Ethnic and Migration Studies 41 (2), 196-218.

Kahanec, M. \& K. Zimmermann. 2016. Labor Migration, EU Enlargement, and the Great Recession. Berlin, Heidelberg: Springer.

Khattab, N. \& Fox, J. 2016. "East-European immigrants responding to the recession in Britain: is there a trade-off between unemployment and over-qualification?" Journal of Ethnic and Migration Studies 42 (11), 1774-1789.

Kingston, G., F. McGinnity \& P. O’Connell. 2015. “Discrimination in the labour market: nationality, ethnicity and the recession." Work, employment and society, Vol 29(2), pp. 213 - 232.

Lehndorff, S. 2015. Divisive integration the triumph of failed ideas in Europe - revisited. Brussels: European Trade Union Institute

Longhi, S. \& M. Rokicka. 2012. "Eastern European Immigrants in the UK Before and After the 2004 European Enlargement.” NORFACE migration discussion paper No. 30: 1-26. Available at: www.norface-migration.org.

Martí, M. \& C. Ródenas. 2007. "Migration Estimation Based on the Labour Force Survey : An EU15 Perspective.” International Migration Review 41(1): 101-126.

McCollum, D. \& A. Findlay. 2015. “"Flexible' workers for 'flexible' jobs? The labour market function of A8 migrant labour in the UK." Work, Employment and Society, 29(3): 427-443 
Nielsen, H.S., M. Rosholm, N. Smith \& L. Husted. 2004. "Qualifications, discrimination, or assimilation? An extended framework for analysing immigrant wage gaps." Empirical Economics 29(4): 855-883.

O’Reilly, J. \& C. Fagan. 1998. Part-time Prospects: International comparisons of part-time work in Europe, North America and the Pacific Rim. London and New York: Routledge

ONS 2015 Consumer Price Inflation, UK Office for National Statistics:

http://www.ons.gov.uk/ons/datasets-and-tables/data-

selector.html?cdid=D7BT\&dataset=mm23\&table-id=1.1, Accessed: 15 Aug 2015.

Parutis, V. 2011. "White, European and Hardworking: East European Migrants' Relationships with Other Communities in London.” Journal of Baltic Studies 42 (2): 263-288.

Peck, J. 1996. "Structuring the labor market. A segmentation approach.” In Work-Place. The Social Regulation of Labor Markets. J. Peck (Ed.) Guilford Press New York/London: 46-80.

Pietka, E., C. Clark \& N. Canton. 2013. “'I know that I have a university diploma and I'm working as a driver'." In Mobility in transition: migration patterns after EU enlargement. B. Glorius,, I. Grabowska-Lusinska \& A. Kuvik (eds.). Amsterdam: Amsterdam University Press

Piore, M. 1979. Birds of Passage - Migrant labor and industrial societies. Cambridge: Cambridge University Press.

RDC of the Federal Statistical Office and Statistical Offices of the Länder, German Microcensus, [2013].

Recchi, E. 2015. Mobile Europe - The theory and practice of free movement in the EU. New York: Palgrave Macmillan.

Rienzo, C. 2013. Migrants in the UK Labour Market : An Overview. Migration Observatory briefing. Oxford: COMPAS, University of Oxford.

Rubery, J. 2007. "Developing segmentation theory: a thirty years perspective.” Économies et Sociétés, 28(6): 941-964. 
Schroedter J. H, Y. Lechert \& P. Lüttinger. 2006. "Die Umsetzung der Bildungsskala ISCED-1997 für die Volkszählung 1970, die Mikrozensus- Zusatzerhebung 1971 und die Mikrozensen 19762004." ZUMA-Methodenbericht 2006-08. Mannheim: ZUMA.

Spreckelsen, T., J. Leschke \& M. Seeleib-Kaiser. (forthcoming) "Europe's promise for jobs? Labor market integration of young EU migrant citizens in Germany and the United Kingdom.” In Youth Labor in Transitions. J. O’Reilly, J. Leschke, R. Ortlieb, M. Seeleib-Kaiser \& P. Villa. (eds.) (forthcoming) Oxford: Oxford University Press.

Trevana, P. 2013. "Why do highly educated migrants go for low-skilled jobs? A case study of Polish graduates working in London." In Mobility in transition: migration patterns after EU enlargement. by B. Glorius, I. Grabowska-Lusinska \& A. Kuvik (eds.). Amsterdam: Amsterdam University Press. Voitchovsky, S. 2014. “Occupational Downgrading and Wages of New Member States Immigrants to Ireland." International Migration Review 48(2): 500-537

Waldinger, R. D. \& M. I. Lichter. 2003. How the Other Half Works. Immigration and the Social Organization of Labor. Berkeley; Los Angeles; London, University of California Press

Warren, T. 2004. “Working part-time: achieving a successful 'work-life' balance?” The British Journal of Sociology 55:1, 99-122.

Wiley, N. F. 1967. “The Ethnic Mobility Trap and Stratification Theory.” Social Problems 15(2), 147-159. 


\section{Figures}

\section{Figure 1}

Table 1: Demographic characteristics of natives and recent immigrants in the data from Denmark, Germany and the UK for individuals aged 16-66, excluding active students.

\begin{tabular}{|c|c|c|c|c|c|c|}
\hline & & Average age & $\%$ Female & $\begin{array}{l}\text { Years since } \\
\text { arrival }\end{array}$ & Case numbers & Sample: \\
\hline \multirow[t]{5}{*}{$\overline{\text { DK }}$} & Danish nationals & 46.9 & $50 \%$ & n.a. & $2,586,544$ & $\begin{array}{l}n=2,627,368 \\
(2014)\end{array}$ \\
\hline & EU-West/EEA & 35.2 & $49 \%$ & 2.7 & 11,443 & \\
\hline & EU-South & 32.9 & $43 \%$ & 2.4 & 3,654 & \\
\hline & EU8 & 33.4 & $45 \%$ & 2.8 & 15,589 & \\
\hline & EU2 & 31.9 & $40 \%$ & 2.6 & 10,138 & \\
\hline \multirow[t]{5}{*}{$\overline{\text { GER }}$} & $\begin{array}{l}\text { German } \\
\text { Nationals }\end{array}$ & 44.7 & $50 \%$ & n.a. & 332,193 & $\begin{array}{l}n=335,546 \\
(2013)\end{array}$ \\
\hline & EU-West/EEA & 36.6 & $45 \%$ & 3.5 & 684 & \\
\hline & EU-South & 35.0 & $42 \%$ & 2.9 & 561 & \\
\hline & EU8 & 34.7 & $51 \%$ & 3.1 & 1,353 & \\
\hline & EU2 & 34.1 & $49 \%$ & 3.2 & 755 & \\
\hline \multirow[t]{5}{*}{ UK } & UK nationals & 41.4 & $50 \%$ & n.a. & 246,711 & $\begin{array}{l}\mathrm{n}=248,978 \\
(2012-14)\end{array}$ \\
\hline & EU-West/EEA & 31.7 & $48 \%$ & 2.7 & 467 & \\
\hline & EU-South & 29.7 & $50 \%$ & 2.4 & 531 & \\
\hline & EU8 & 29.6 & $49 \%$ & 2.8 & 847 & \\
\hline & EU2 & 31.9 & $55 \%$ & 2.9 & 422 & \\
\hline
\end{tabular}

Source: Authors' calculations based on Danish administrative register 2014, German Microcensus 2013 and UK quarterly Labour Force Survey (UK-LFS) 2012-2014, pooled.

Note: The table only contains information on individuals between the ages of 16 and 66 who are not active as students and only information on immigrants who have settled within the last five years, excluding immigrants who settled during the last year. 


\section{Figure 2}

Table 2: Logit estimates of being active on the labour market (labour force participation) for individuals aged 16-66, excluding active students, in Denmark, Germany and the UK.

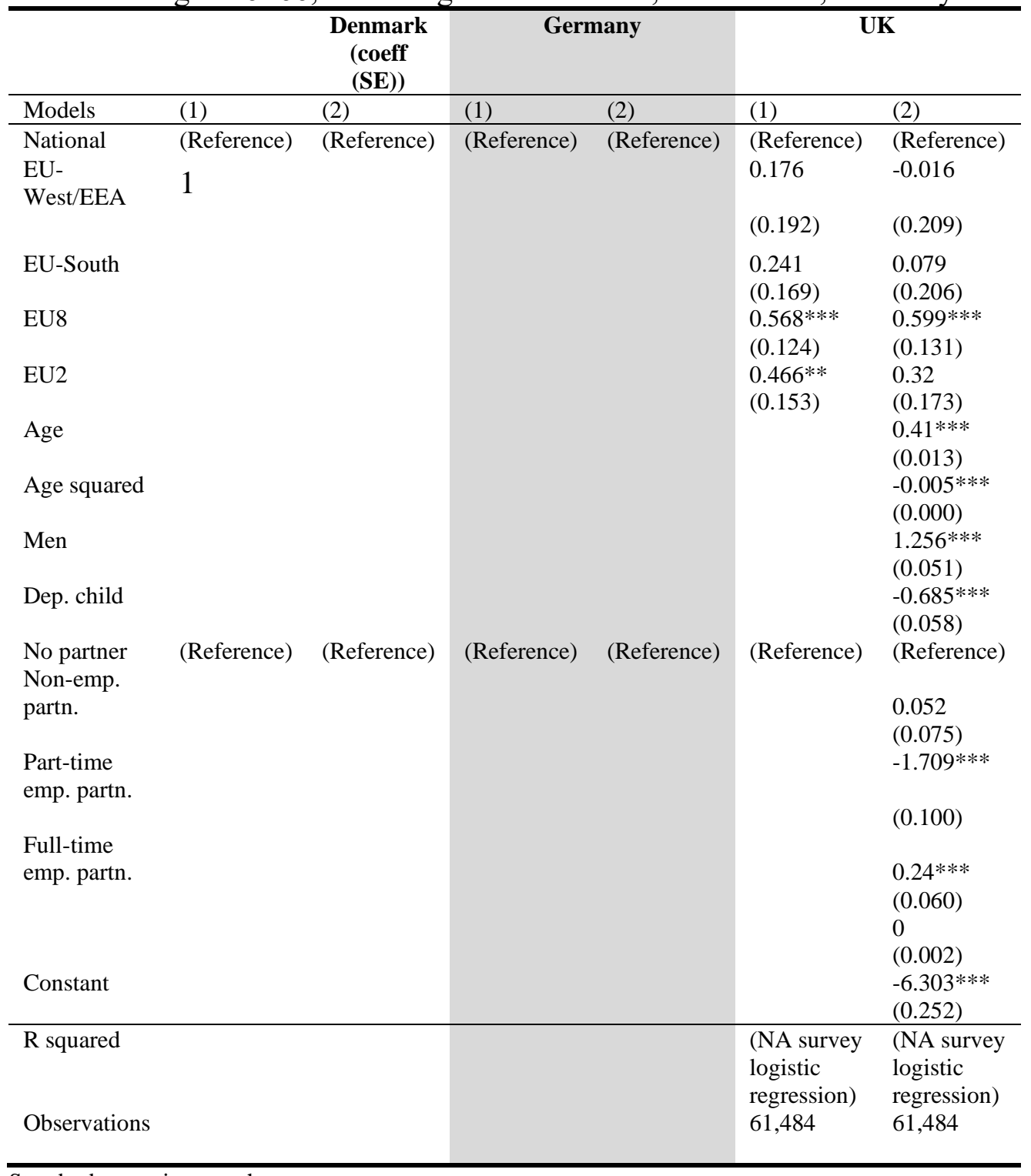

Standard errors in parentheses

${ }^{*} p<0.05,{ }^{* *} p<0.01,{ }^{* * *} p<0.001$

Source: Authors' calculations based on Danish administrative register 2014, German Microcensus 2013 and UK quarterly Labour Force Survey (UK-LFS) 2012-2014, pooled. 


\section{Figure 3}

Table 3: OLS estimates of logged hourly wages for employed individuals aged 16-66, excluding active students, 2014 (2013 for DE) (coeff (SE))

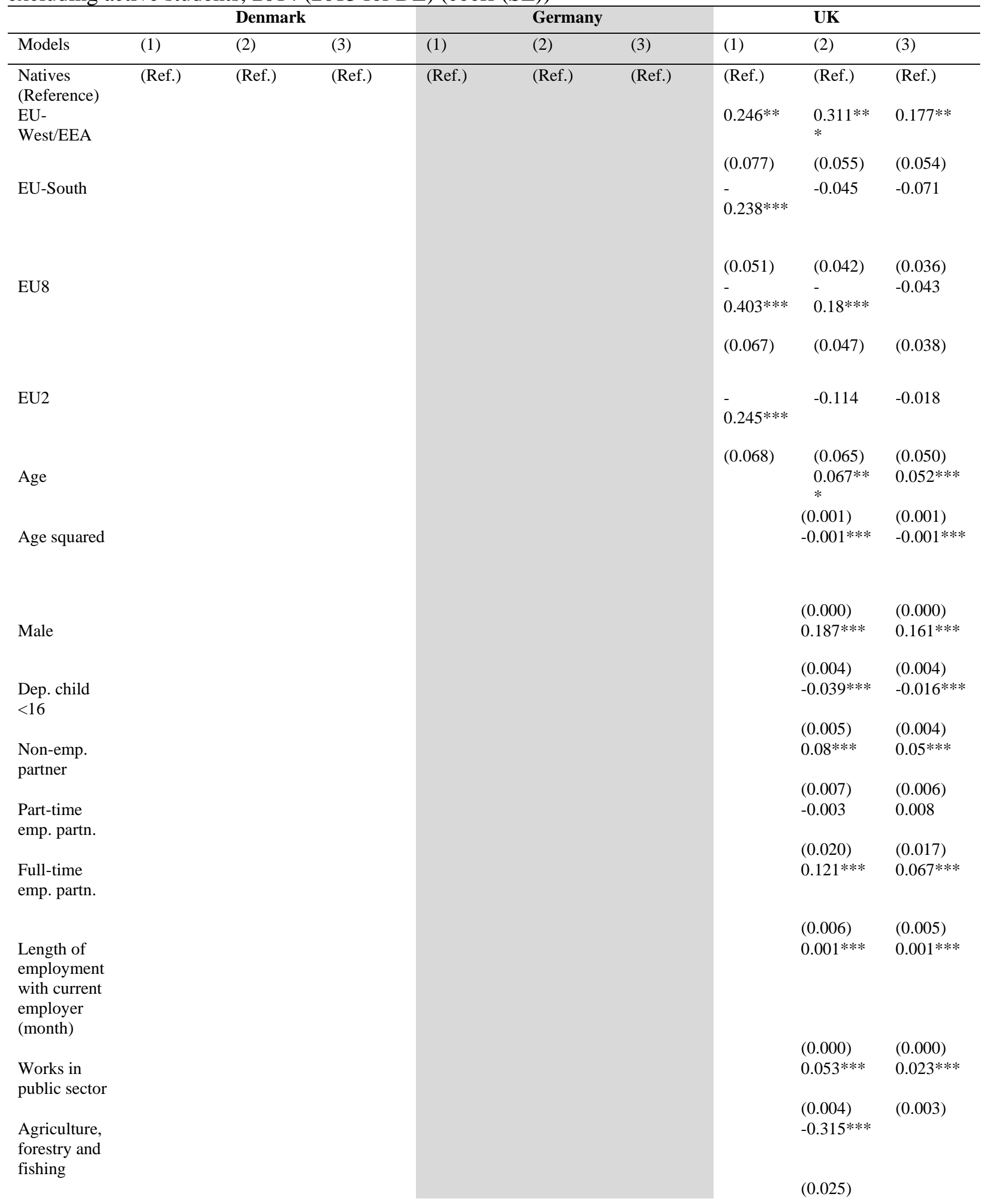




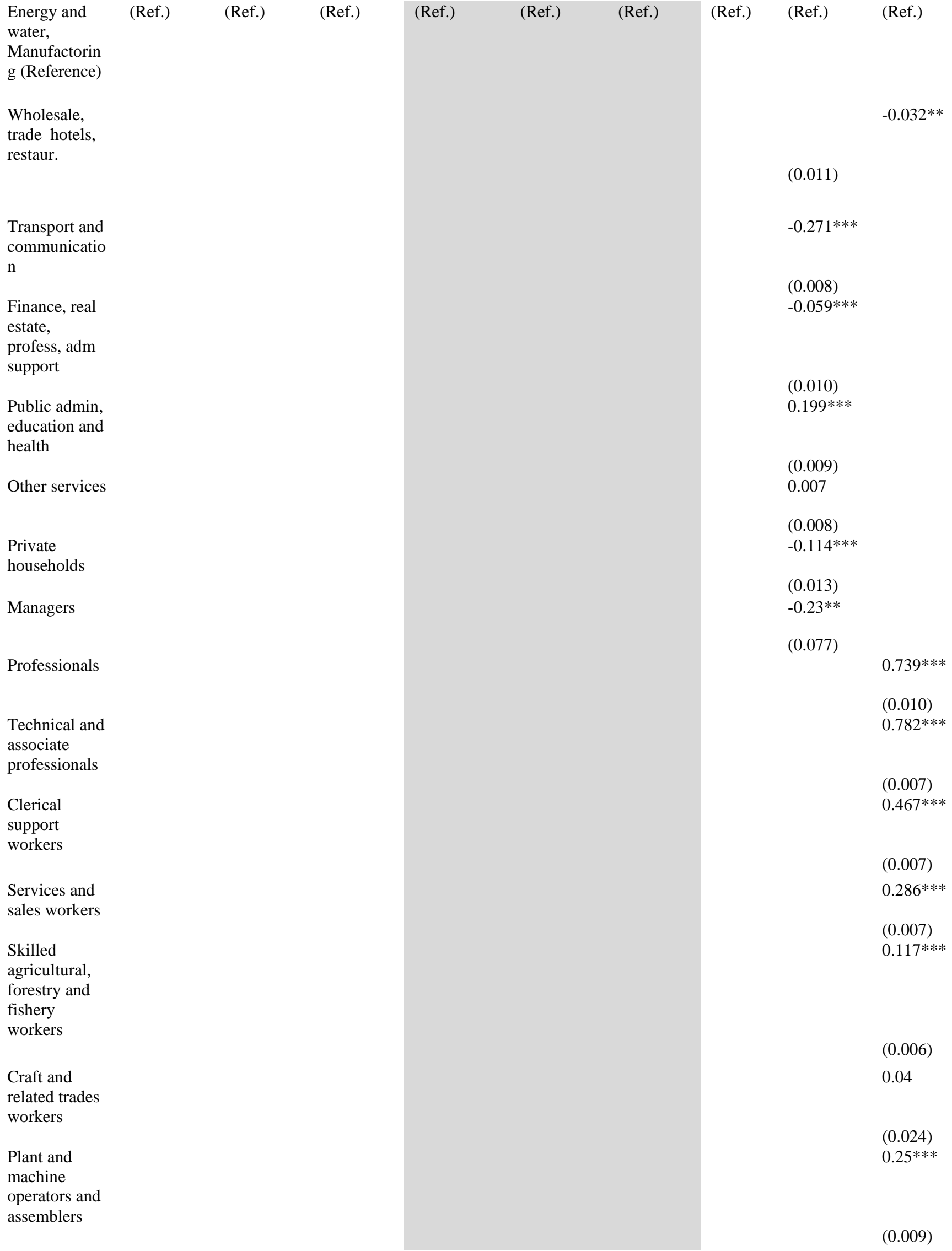




\begin{tabular}{l|llll}
$\begin{array}{l}\text { Elementary } \\
\text { occupations } \\
\text { (Reference) }\end{array}$ & & & & \\
& & & \\
& & & \\
Constant & $2.415^{* * *}$ & $0.845^{* * *}$ & $0.732^{* * *}$ \\
& $*$ & $(0.003)$ & $(0.025)$ & $(0.023)$ \\
\hline R squared & 0.004 & 0.247 & 0.417 & 1504 \\
Observations & 154798 & 154798 & 154798 \\
\hline
\end{tabular}

Standard errors in parentheses

${ }^{*} p<0.05,{ }^{* * *} p<0.01,{ }^{* * *} p<0.001$

Source: Authors' calculations based on Danish administrative register 2014, German Microcensus 2013 and UK quarterly Labour Force Survey (UK-LFS) 2012-2014, pooled. 